\title{
A Facile Synthesis of 5-lodo-6-Substituted Pyrimidines from Uracil-6-Carboxylic acid (Orotic acid)
}

\author{
Tanvir Sultana and Md. Wahab Khan \\ Department of Chemistry, Bangladesh University of Engineering and Technology, Dhaka-1000, Bangladesh.
}

\begin{abstract}
Dichloro-pyrimidine-6-carbonylchloride (2) was synthesized by refluxing orotic acid (1) with phosphorus oxychloride and phosphorus pentachloride. Compound (2) underwent a smooth Friedel-Craft's reaction with a number of substituted benzene to yield 2,4-Dichloro-6-aroylpyrimidines $\mathbf{6}$ and $\mathbf{7}$ which were converted to the corresponding dimethoxy pyrimidines $(\mathbf{8}, \mathbf{9})$ on treatment with sodium methoxide in methanol. The iodination reaction on 2,4-dimethoxy-6-aroylpyrimidines $(\mathbf{8}, \mathbf{9})$ was attempted by several methods but only NIS-TFA-TFAA method gave the desired products, 2,4-dimethoxy-5-iodo-6-aroylpyrimidine $(\mathbf{1 0}, \mathbf{1 1})$ in good yields.
\end{abstract}

Key words: Synthesis, 5-Iodo-6-Substituted pyrimidines, Orotic acid.

\section{INTRODUCTION}

Idoxuridine (IDU) I and Trifluorothymidine (TFT) II were the first pyrimidine nucleoside ${ }^{1}$ analogues ever shown to be effective against herpesviruses in particular HSV-1. They were also the first to be approved for clinical use, and are, as of today, still used as eye drops in the topical treatment of HSV-1 keratitis. However, neither IDU nor TFT can be used systematically because they are too toxic, especially to the bone marrow. The importance of 5substituted derivatives of uracil as anticancer and antiviral (including anti-AIDS) agents is wellestablished. For example, 5-fluorouracil (5-FU) III and the corresponding 2-deoxyribonucleoside $(\mathrm{FUdR})^{2}$ have been of importance in cancer chemotherapy for decades.

Dihydroalkoxybenzyloxopyrimidines (DABOs) are a new class of specific inhibitors of human immunodeficiency virus type 1 (HIV-1) which possess a benzyl moiety and an alkyl (cycloalkyl) chain linked through an oxygen bridge to the uracil or

Correspondence to: Wahab Khan

E-mail:mwkhan@chem.buet.ac.bd

Dhaka Univ. J. Pharm. Sci.12(2): 97-102, 2013 (December)<smiles>O=c1[nH]cc(F)c(=O)[nH]1</smiles><smiles></smiles><smiles>O=C1NC(=O)N2C=C(C(F)(F)F)C(O)=C3C(O)CC1N32</smiles>

thymine base. $^{3-5}$ Various thio analogues ${ }^{6}$ of dihydroalkoxybenzyloxopyrimidines (DABOs), a new class of non-nucleoside reverse transcriptase inhibitors, were found to be selectively inhibit the HIV-1 multiplication in vitro. 5-Isopropyl-2[(methylthiomethyl)thio]-6-(benzyl)-pyrimidin-4$(1 H)$-one $^{7}$ was found to be potent anti-HIV activity with an $\mathrm{IC}_{50}$ value of less than $1 \mathrm{nM}$ for inhibition of 
HIV replication-without any evidence of cytotoxicity. 6-Substituted-2-[(4-hydroxybutyl)amino]-4(3H)pyrimidinones was found as HIV-1 RT active inhibitor. ${ }^{8}$ Several 6-benzyl 1-[(2-hydroxyethoxy) methyl]-6-phenylthio) thymine (HEPT) have shown potent and selective in vitro activity against HIV-1. ${ }^{9}$ The antiviral activities of a series of 6-arylmethyl-1allyloxymethyl)-5-alkyluracil derivatives were found. ${ }^{10}$ Iodo derivatives of pyrimidines and uracils have been utilized for the synthesis of corresponding carbon substituted derivatives. ${ }^{11}$ Thus, the availability of suitable iodo derivatives of pyrimidines and uracils become important. Recently, we have reported a synthesis of 4-acyl-2,6-dioxo-1,2,3,6-tetrahydropyrimidines (6-acyluracils and 4-acyl-6-aryl-2-oxo-2, 3-dihydropyrimidines. ${ }^{12}$ In connection to our studies on orotic acid, we needed a large quantity of 5-iodo2,4-dimethoxypyrimidine.

\section{MATERIALS AND METHODS}

Melting points were determined in open capillary tubes on Gallenkamp (England) melting point apparatus and were uncorrected. IR spectra were recorded on a Shimadzu FTIR spectrophotometer and UV spectra were recorded in dry EtOH with a Shimadzu visible spectrometer. ${ }^{1} \mathrm{H}$ NMR and ${ }^{13} \mathrm{C}$ NMR spectra were recorded on a Bruker DPX - 400 spectrometer $(400-\mathrm{MHz})$ using TMS as internal reference. Analytical thin-layer chromatography (TLC) was performed on precoated silica gel $60 \mathrm{~F}_{254}$ (E. Merck), and the spots were visualized with UV light. Column chromatography was performed on silica gel (60-120 mesh). Elemental analyses (C, H, N) were carried out on a Perkin- Elmer $240 \mathrm{C}$ analyser. Orotic acid, $\mathrm{POCl}_{3}$, primary arylamine, NIS, TFA, TFAA and other reagents were purchased from E. Merck (Germany) and Fluka (Switzerland).

Preparation of 2,4-Dichloropyrimidine-6-carbonyl chloride (2), A mixture of 2,4-dioxo-1,3,5trihydropyrimidine-6-carboxylic acid (orotic acid) 5.0 $\mathrm{g}(0.032 \mathrm{~mol})$ and phosphorus oxychloride $\left(\mathrm{POCl}_{3}, 40\right.$ $\mathrm{ml})$ was refluxed for 24 hours at $105-108{ }^{\circ} \mathrm{C}$, then phosphorus pentachloride (15 g, $0.072 \mathrm{~mol})$ was added into the reaction mixture. ${ }^{13}$ The mixture was then refluxed for 24 hours. Phosphorus oxychloride was recovered under reduced pressure. The residue was distilled under reduced pressure and 2, 4dichloropyrimidine-6-carbonyl chloride (2), (4.0 g) was obtained as dense colorless liquid.

Synthesis of 2,4-dichloro-6-aroylpyrimidines (6,7). To the substituted benzenes 4, $5(60 \mathrm{ml})$ anhydrous aluminium chloride $(6 \mathrm{~g})$ was added at 0 ${ }^{\circ} \mathrm{C}$. To the cold solution 2, 4-dichloropyrimidine-6carbonyl chloride (2) (6 g) was added slowly. The mixture was allowed to warm up to room temperature and stirred for 5-6 hours and poured into cold hydrochloric acid solution $(2 \mathrm{ml}, 12 \mathrm{M} \mathrm{HCl}$ in $60 \mathrm{ml}$ water). The mixture was extracted with chloroform (3 x $25 \mathrm{ml})$. The combined organic layer was washed with sodium bicarbonate, distilled water and dried over anhydrous sodium sulfate. After removal of solvent, the product was purified by column chromatography over silica gel and then it was crystallized to afford the desired products $\mathbf{6}$ and $\mathbf{7}$ in good yield.

2,4-Dichloro-6-p-bromobenzoylpyrimidine (6). Colourless needles $\left(\mathrm{CCl}_{4}\right)$, mp 122-124 ${ }^{\circ} \mathrm{C}$; IR: $v_{\max }$ (KBr) 3112.9, 3070.5, 1664.5, 1587.3, 1548.7, $1519.8,1401.2,1325.0,1303.8,1325.0,1246.9$, 1217.0, 1181.3, 1071.4, 1011.6, 975.9, 847.7, 833.2, 790.8, 773.4, 742.5, 691.4, 606.6, $484.1 \mathrm{~cm}^{-1}$; UV: $\lambda_{\max } 284.80 \mathrm{~nm} ;{ }^{1} \mathrm{H}$ NMR $\left(400 \mathrm{MHz} \mathrm{CDCl}_{3}\right) \delta$ $7.67(2 \mathrm{H}, \mathrm{d}, J=8.5 \mathrm{~Hz}, \mathrm{Ar}-\mathrm{H}), 7.88(1 \mathrm{H}, \mathrm{s}, \mathrm{C}-5 \mathrm{H})$, $8.01(2 \mathrm{H}, \mathrm{d}, J=8.5 \mathrm{~Hz}, \mathrm{Ar}-\mathrm{H}) ;{ }^{13} \mathrm{C}$ NMR $(100 \mathrm{MHz}$ $\left.\mathrm{CDCl}_{3}\right) \delta 119.7$ (Py-CH), 130.2, $132.0(\mathrm{Ar}-\mathrm{H}), 132.4$, 132.6 (Ar-C), 160.2, 164.2, 164.6 (Py-C), 188.1 $(\mathrm{C}=\mathrm{O})$.

Anal. Calcd for $\mathrm{C}_{11} \mathrm{H}_{5} \mathrm{~N}_{2} \mathrm{OBrCl}_{2}$ : C, 39.80; $\mathrm{H}$ $1.52 ; \mathrm{N}, 8.44$. Found: C, 39.73, H, 1.58; N, 8.34.

\section{2,4-Dichloro-6-p-methoxyl benzoyl pyrimidine} (7). Yellow crystals $\left(\mathrm{CCl}_{4}\right)$; mp $110-112{ }^{\circ} \mathrm{C}$; IR: $v_{\max }$ (KBr) 1652.9, 1596.9, 1552.6, 1519.8, 1508.2, $1323.1,1278.7,1257.5,1168.8,1118.6,1033.8$, 846.7, 781.1, 756.0, 746.4 and $607 \mathrm{~cm}^{-}{ }^{1}$; UV (EtOH): $\lambda_{\max } 278.80,224.60 \mathrm{~nm} ;{ }^{1} \mathrm{H}$ NMR (400 $\left.\mathrm{MHz}, \mathrm{CDCl}_{3}\right) \delta 3.90\left(3 \mathrm{H}, \mathrm{s}, \mathrm{ArOCH}_{3}\right), 6.98(2 \mathrm{H}, \mathrm{d}, J$ $=9 \mathrm{~Hz}, \mathrm{ArH}), 7.80(1 \mathrm{H}, \mathrm{s}, \mathrm{C}-5 \mathrm{H}), 8.12(2 \mathrm{H}, \mathrm{d}, J=9$ $\mathrm{Hz}, \mathrm{ArH})$. 
Preparation of 2,4-dimethoxy-6-aroylpyrimidines $(8,9)$. 2, 4-Dichloro-6-p-aroylpyri-midine 6, $7(1.6506 \mathrm{mmol})$ was added dropwise to an ice-cold solution of sodium $(0.1138 \mathrm{~g})$ in dry methanol (30 $\mathrm{mL}$ ). The whole solution was refluxed at $80{ }^{\circ} \mathrm{C}$ for 4 hours. A solid mass was obtained after removal of solvent. To this solid mass $100 \mathrm{~mL}$ water was added and neutralized by dilute hydrochloric acid. Then it was extracted with chloroform $(50 \mathrm{~mL} \times 3)$. The organic layer was then washed with $10 \% \mathrm{NaHCO}_{3}$, water and dried over $\mathrm{Na}_{2} \mathrm{SO}_{4}$ (anhyd.). After removal of the solvent solid was obtained and crystallized from methanol. A needle shaped crystal was obtained in good yield.

\section{2,4-Dimethoxy-6-p-bromobenzoyl pyrimidine}

(8). Colourless needle (methanol); yield $450 \mathrm{mg} . \mathrm{mp}$ 121-122 ${ }^{\circ} \mathrm{C}$; IR: $v_{\max }(\mathrm{KBr}) 1674.1,1582.5,1559.3$, $1484.1,1463.9,1395.4,1386.4,1349.1,1259.4$, 12054, 1105.1, 974.9, 835.3, $763.8 \mathrm{~cm}^{-1}$; UV(EtOH) : $\lambda_{\max } 277.20 \mathrm{~nm} ;{ }^{1} \mathrm{H}$ NMR $\left(400 \mathrm{MHz}, \mathrm{CDCl}_{3}\right) \delta$ 4.01(3H, s, $\left.\mathrm{OCH}_{3}\right), 4.04\left(3 \mathrm{H}, \mathrm{s}, \mathrm{OCH}_{3}\right), 6.93(1 \mathrm{H}, \mathrm{s}$, C-5H), 7.63 (2H, d, J = 8.6 Hz, ArH), 8.00 (2H, d, $J$ $=8.6 \mathrm{~Hz}, \mathrm{ArH}) ;{ }^{13} \mathrm{C}$ NMR $\left(100 \mathrm{MHz}, \mathrm{CDCl}_{3}\right) \delta 54.3$ $\left(\mathrm{OCH}_{3}\right), 55.1\left(\mathrm{OCH}_{3}\right), 102.0(\mathrm{C}-5 \mathrm{H}), 128.8$ (Ar-C), 132.2 (Ar-CH), 133.9 (Ar-C), 163.1, 165.0, 172.7 (Py-C), $190.8(\mathrm{C}=\mathrm{O})$.

Anal. Calcd for $\mathrm{C}_{13} \mathrm{H}_{11} \mathrm{~N}_{2} \mathrm{BrO}_{3}$ : C, 48.32; H, 3.43; N, 8.60. Found: C, 48.97; H, 3.42; N, 8.50.

2,4-Dimethoxy-6-p-methoxybenzoyl pyrimidine (9). Light yellow needle (methanol); mp 139$141^{\circ} \mathrm{C}$; IR: $v_{\text {max }}(\mathrm{KBr}) 3190,1658.7,1598.9,1558.4$, $1427.2,1388.7,1350.1,1182,1182.3$, and 1095.5 $\mathrm{cm}^{-1}$; UV(EtOH): $\lambda_{\max } 296.60,214.20 \mathrm{~nm} ;{ }^{1} \mathrm{H}$ NMR $\delta\left(400 \mathrm{MHz}, \mathrm{CDCl}_{3}\right) 3.88\left(3 \mathrm{H}, \mathrm{s}, \mathrm{Ar}-\mathrm{OCH}_{3}\right) 4.02$ $\left(3 \mathrm{H}, \mathrm{d}, \mathrm{OCH}_{3}\right), 4.03\left(3 \mathrm{H}, \mathrm{s}, \mathrm{OCH}_{3}\right), 6.85\left(\mathrm{H}, \mathrm{s}, \mathrm{C}_{5}-\right.$ H), $6.96(2 \mathrm{H}, \mathrm{d}, J=8 \mathrm{~Hz}, \mathrm{Ar}-\mathrm{H}) 8.13(2 \mathrm{H}, \mathrm{d}, J=8$ $\mathrm{Hz}, \mathrm{Ar}-\mathrm{H})$

Preparation of 2,4-dimethoxy-6-methyl orotate (3). 2,4-Dichloro pyrimidine-6-carboxyl chloride 2 ( $1 \mathrm{~m} \mathrm{~mol})$ in dry methanol $(50 \mathrm{ml})$ was added drop wise to an ice-cold solution of sodium $(1.95 \mathrm{~g}, 0.084$ $\mathrm{mol})$ in dry methanol $(50 \mathrm{ml}$. The whole solution was stirred at room temperature for 4 hours. After removal of solvent a solid mass was obtained. To this solid mass $100 \mathrm{~mL}$ water was added and neutralized by dilute hydrochloric acid. Then it was extracted with chloroform $(50 \mathrm{~mL} \times 3)$. The organic layer was then washed with water, $10 \% \mathrm{NaHCO}_{3}$ and dried over anhyd. $\mathrm{Na}_{2} \mathrm{SO}_{4}$. After removal of chloroform the solid mass was obtained and crystallized from methanol. A needle shaped crystal was obtained. mp 106- $107^{\circ} \mathrm{C}$; IR: $v_{\max }(\mathrm{KBr}) 1724.2,1600.8,1569.0$, $1439.0,1435.9,1393.5,1271.0,1286.4,1353.9$, 1119.6, 1125.1, 1102.2, 780.2, and $772.4 \mathrm{~cm}^{-1}$; UV: $\lambda_{\max } 280.40,225.40 \mathrm{~nm} ;{ }^{1} \mathrm{H}$ NMR $\left(400 \mathrm{MHz}, \mathrm{CDCl}_{3}\right)$ $\delta 3.97\left(3 \mathrm{H}, \mathrm{s}, \mathrm{OCH}_{3}\right), 4.03\left(3 \mathrm{H}, \mathrm{s}, \mathrm{OCH}_{3}\right), 4.07(3 \mathrm{H}$, $\left.\mathrm{s}, \mathrm{COOCH}_{3}\right), 7.07\left(1 \mathrm{H}, \mathrm{s}, \mathrm{C}-{ }_{5} \mathrm{H}\right) ;{ }^{13} \mathrm{C}$ NMR $(100$ $\left.\mathrm{MHz}, \mathrm{CDCl}_{3}\right) \delta 52.9\left(\mathrm{OCH}_{3}\right), 54.3\left(\mathrm{OCH}_{3}\right), 55.0$ $\left(\mathrm{COOCH}_{3}\right), 103.1$ (Py-H), 156.7 (Py-C), 164.4 (PyC), 165.7 (Py-C), 172.7 (C=O).

Anal. Calcd for $\mathrm{C}_{8} \mathrm{H}_{10} \mathrm{~N}_{2} \mathrm{O}_{4}: \mathrm{C}, 48.48, \mathrm{H}, 5.09, \mathrm{~N}$, 14.14. Found: C, 48.90; H, 5.02, N, 13.76.

Synthesis of 2, 4-dimethoxy-5-iodo-6-aroyl pyrimidines $(\mathbf{1 0}, \mathbf{1 1})$. A mixture of 2, 4-dimethoxy6-p-aroylpyrimidine $\quad(500 \mathrm{mg}, \quad 1.6954 \mathrm{mmol})$ trifluoroacetic acid $(50 \mathrm{ml}$ and trifluoroacetic anhydride (1 ml was refluxed for 20 minutes. $N$ Iodosuccinimide (1.2 equiv, $457.74 \mathrm{mg}$ ) was added and the reaction mixture was further refluxed for 8 hours. The reaction mixture was allowed to cool to room temperature and the solvent was removed under reduced pressure. The residue was dissolved in chloroform $(300 \mathrm{ml}$, and successively washed with water $(50 \mathrm{ml})$, saturated sodium bicarbonate $(2 \times 40$ $\mathrm{ml}$, saturated sodium thiosulfates $(2 \times 40 \mathrm{ml}$ and water $(2 \times 40 \mathrm{ml}$. The chloroform layer was dried over anhyd. Sodium sulfate and concentrated to dryness to give $1.15 \mathrm{~g}$ crude mass. The crude mass was crystallized from methanol.

2,4-Dimethoxy-5-iodo-6-p-bromobenzoyl pyrimidine (10). Light yellow crystals, mp $185-186{ }^{\circ} \mathrm{C}$; IR: $v_{\max }(\mathrm{KBr}) 2958.0,1681.8,1576.7,1588.3$, $1555.5,1479.3,1449.4,1403.1,1379.0,1364.5$, 1248.8, 1227.6, 1069.5, 1017.4, 1010.6, 979.8, 931.6, 849.6, 784.0 and $768.6 \mathrm{~cm}^{-1}$; ${ }^{1} \mathrm{H}$ NMR $(400 \mathrm{MHz}$, $\left.\mathrm{CDCl}_{3}\right) \delta 3.97\left(3 \mathrm{H}, \mathrm{s}, \mathrm{OCH}_{3}\right), 4.10\left(3 \mathrm{H}, \mathrm{s}, \mathrm{OCH}_{3}\right)$, $7.62(2 \mathrm{H}, \mathrm{d}, J=7.2 \mathrm{~Hz}, \operatorname{Ar}-\mathrm{H}), 7.73(2 \mathrm{H}, \mathrm{d}, J=7.2$ $\mathrm{Hz}, \operatorname{ArH}) ;{ }^{13} \mathrm{C}$ NMR $\left(100 \mathrm{MHz}, \mathrm{CDCl}_{3}\right) \delta 55.6$ 
$\left(\mathrm{OCH}_{3}\right)$, 55.7 $\left(\mathrm{OCH}_{3}\right), 65.68$ (Py-C), 129.90 (Ar-C), 131.6, 132.27(Ar-CH), 133.33 (Ar-C), 165.8, 168.6, 169.7 (Py-C), $191.8(\mathrm{C}=\mathrm{O})$.

2,4-Dimethoxy-5-iodo-6-p-methoxy-m-iodobenzoyl pyrimidine (11). Light yellow crystals, mp 1181-119 ${ }^{\circ} \mathrm{C}$; IR: $v \max _{\text {max }}(\mathrm{KBr}) 1651.0,1577.7$, 1562.25, 1477.4, 1380.9, 1352. 0, 1269.1, 1201.6, 1049.2 and $767.6 \mathrm{~cm}^{-1}$; ${ }^{1} \mathrm{H}$ NMR (400 MHz, $\mathrm{CDCl}_{3}$ ) $\delta 3.96\left(3 \mathrm{H}, \mathrm{s}, \mathrm{Ar}-\mathrm{OCH}_{3}\right), 4.03\left(6 \mathrm{H}, \mathrm{s}, \mathrm{C}-2, \mathrm{OCH}_{3}\right.$ and $\left.\mathrm{C}_{-4} \mathrm{OCH}_{3}\right), 6.86(1 \mathrm{H}, \mathrm{d}, J=8.6 \mathrm{~Hz}, \mathrm{Ar}-\mathrm{H}), 8.18 .(1 \mathrm{H}$, d, $J=8.6 \mathrm{~Hz}, \mathrm{Ar}-\mathrm{H}), 8.69(1 \mathrm{H}, \mathrm{s}, \mathrm{Ar}-\mathrm{H}) ;{ }^{13} \mathrm{C} \mathrm{NMR}$ $\left(100 \mathrm{MHz}, \mathrm{CDCl}_{3}\right) \delta 54.47\left(\mathrm{OCH}_{3}\right) 55.34\left(\mathrm{OCH}_{3}\right)$, $56.78\left(\mathrm{OCH}_{3}\right), 85.53$ (Py-C), 102.17 (Ar-CH ), $110.02,129.86$ (Ar-C), 133.23, 142.87(Ar-CH), 142.98 (Ar-C), 162.27, 163.75, 172(Py-C) and $189.03(\mathrm{C}=\mathrm{O})$.

2,4-Dimethoxy-5-iodo-6-methylorotate (12). 2, 4-Dimethoxy-5-iodo-6-methyl orotate $\mathbf{1 2}$ was prepared from 2, 4-dimethoxy-6-methylorotate 3 (2.2 g $0.1138 \mathrm{mmol}$ ) by using the above iodination procedure. The crude mass was crystallized from methanol. Light yellow crystals, mp $167-168{ }^{\circ} \mathrm{C}$; IR: $v_{\max }(\mathrm{KBr}) 1728.1,1553.6,1486.1,1454.2,1437.8$,<smiles>O=C(O)c1cc(Cl)nc(Cl)n1</smiles>

Scheme 1<smiles>Clc1cc(C(Cl)(Cl)Cl)nc(Cl)n1</smiles>

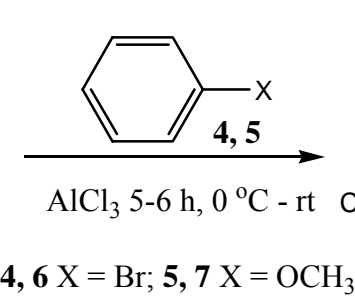

$1383.8,1354.9,1234.4,1198.7,1169.7,1108.0$, 1039.6, 1016.4, 965.3 and $786.9 \mathrm{~cm}^{-1}$; UV(EtOH): $\lambda_{\max } 286.80,234.80 \mathrm{~nm} ;{ }^{1} \mathrm{H}$ NMR $\left(400 \mathrm{MHz}, \mathrm{CDCl}_{3}\right)$ $\delta 3.92\left(3 \mathrm{H}, \mathrm{s}, \mathrm{OCH}_{3}\right), 3.95\left(3 \mathrm{H}, \mathrm{s}, \mathrm{OCH}_{3}\right), 4.00(3 \mathrm{H}, \mathrm{s}$, $\left.\mathrm{COOCH}_{3}\right) ;{ }^{13} \mathrm{C}$ NMR $\left(100 \mathrm{MHz}, \mathrm{CDCl}_{3}\right) \delta 53.0$ $\left(\mathrm{OCH}_{3}\right), 54.3\left(\mathrm{OCH}_{3}\right), 55.5\left(\mathrm{OCH}_{3}\right), 66.57,103.6$, 162.0, 165.38, 169.97(C=O).

Anal. Calcd for $\mathrm{C}_{8} \mathrm{H}_{9} \mathrm{~N}_{2} \mathrm{O}_{4} \mathrm{I}$ : (C, 29.65, H, 2.80; N, 8.64. Found: C, 30.17, H, 2.80, N, 8.66.

\section{RESULTS AND DISCUSSION}

2,4-Dichloropyrimidine-6-carbonyl chloride (2) was synthesized according to the procedure of Gershon ${ }^{13}$ by heating orotic acid (1) with phosphorus oxychloride and phosphorus pentachloride as shown in the scheme 1.

Compound 2 underwent a smooth Friedel-Crafts reaction with a number of substituted benzene derivatives in the presence of anhydrous aluminium chloride in which the acid chloride moiety was found to react predominantly as shown in the scheme 2 .

\section{Scheme 2}

The yields of the Friedel-Craft's products were good $(70-87 \%)$. The Friedel-Crafts reaction took place at the $p$-position of the substituent on the benzene ring The Friedel-Crafts reaction of 2,4dichloropyrimidine-6-carbonylchloride
(2) and benzene derivatives with electron with drawing substituents on the benzene ring, e.g. benzophenon, p-nitrotoluene and 2-methyl benzaldehyde, however failed. Similarly, phenyl acetylene and styrene failed to give desired products. 
6-Aroyl-2,4-dichloropyrimidines $\quad(\mathbf{6 , 7}) \quad$ were converted to the corresponding 2, 4-dimethoxy pyrimidines $(\mathbf{8 , 9})$ on treatment with sodium methoxide in methanol as shown in the scheme 3.

\section{2,4- Dichloropyrimidine-6-carbonyl chloride was} also converted to 2,4-dimethoxypyrimidine-6methylorotate (3) by refluxing with sodium methoxide in methanol for $4 \mathrm{hrs}$.

In view of the extensive use of iodo derivatives of pyrimidine for the synthesis of the corresponding carbon-substituted derivatives, we attempted to synthesis 5-iodopyrimidines by using different methods. The iodination reaction was attempted by several methods, such as, $\mathrm{I}_{2}$ in alkali solution, $\mathrm{ICl}$ in methanol, $\mathrm{I}_{2}$ in $\mathrm{CHCl}_{3}$ in presence of nitric acid, and $\mathrm{NaI}$ in DMF but only NIS-TFA-TFAA method gave the desired products. The iodination reaction of 2, 4dichloro-6-aroyl pyrimidine was carried out by using NIS-TFA-TFAA under refluxing condition but desired compound 5-iodo pyrimidine was not obtained.

When 2, 4-dimethoxy-6-aroyl pyrimidines $(\mathbf{8}, \mathbf{9})$ were subjected to iodination reaction utilizing NISTFA-TFAA under refluxing condition as shown in the scheme 4 , the desired product 2, 4-dimethoxy-5iodo-6-aroylpyrimidines $(\mathbf{1 0}, \mathbf{1 1})$ were obtained in good yield.

2,4-Dimethoxy-6-methyl orotate (3) was also subjected to iodination reaction using NIS-TFATFAA under the same condition to afford 2, 4dimethooxy-5-iodo 6-methyl orotate (12) as shown in the scheme 5 .<smiles>[X]c1ccc(OC(=[R19][Ba])c2cc(OC)nc(OC)n2)cc1</smiles>

Scheme 3<smiles>[X]c1ccc(OC(=O)c2cc(OC)nc(OC)n2)cc1</smiles>

8, $10 \mathrm{X}=\mathrm{Br} ; 9,11 \mathrm{X}=\mathrm{OCH}_{3} ; 10 \mathrm{Y}=\mathrm{H} ; 11 \mathrm{Y}=\mathrm{I}$

Scheme 4

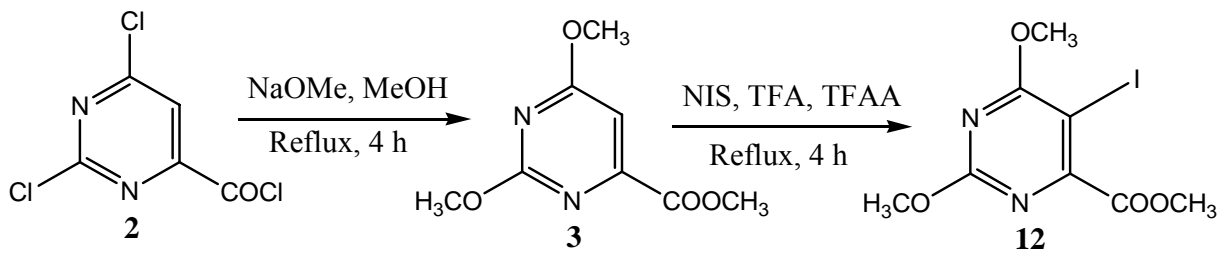

Scheme 5

$N$-Iodosuccinimide in trifluoroacetic acid and trifluoroacetic anhydride was found to be an excellent reagent for the iodonation at C-5 position of 2, 4dimethoxy-6-substituted pyrimidine.

\section{CONCLUSION}

Here, we have demonstrated a convenient and facile method for the synthesis of 2, 4-dichloro-6- $p$ aroyl-pyrimidine and 2, 4-dicholoro-6-methyl orotate 
and their corresponding 2, 4-dimethoxy pyrimidine. Iodination at C-5 position also described here. $\mathrm{N}$ iodosuccinimide in trifluoroacetic acid and trifluoroacetic anhydride was found to be excellent reagents for the iodination at $\mathrm{C}-5$ position of 2, 4dimethoxy-6-aroyl pyrimidine and 2, 4-dimethoxy-6methyl orotate. The most important features of the synthesis are that readily available starting materials are used under relatively mild reaction conditions. Also, no toxic and hazardous compounds are produced by these syntheses. A variety of functional groups can be introduced at the $\mathrm{C}-5$ and $\mathrm{C}-6$ position of the pyrimidine ring by this procedure. Through this methodology biologically important uracil and pyrimidine derivatives can be easily synthesized. 2 , 4-Dimethoxy-5-iodo-6-aroyl pyrimidine might be used as an intermediate for the synthesis of biologically important compounds. This method will be attractive to both organic and medicinal chemists.

\section{ACKNOWLEDGEMENTS}

Financial support from Bangladesh University of Engineering and Technology, Dhaka, Bangladesh is gratefully acknowledged. We are grateful to Prof. Koichi Kato, Nagoya City University, Nagoya, Japan, for taking CHN analyses. Thanks are also due to Prof. Kazuaki Shimada, Iwate University, Morioka, Japan, for taking NMR spectra.

\section{REFERENCES}

1. De Clerck, E. 1995. Trends in the development of new antiviral agents for the chemotherapy of infections caused by herpes viruses and retroviruses. Medical Virology. 5, 149164

2. Heidelberger, C. 1984. Pyrimidine and pyrimidine antimetabolities in cancer medicine (Holland JF, Frei E, eds) Lea and Febiger, Philadelphia, PA, pp. 801-824.

3. Artico, M., Massa, S., Mai, A., Marongiu, M. E., Piras, G., Tramontano, E. and La colla, P. 1993. 3, 4-Dihydro-2alkoxy-6-benzyl-4-oxopyrimidinees (DABOs): A New Class of Specific Inhibitors of Human Immunodeficiency Virus Type 1. Antiviral Chem. Chemther. 4, 361-368.

4. Tramontano, E., Marongiu, M. E., De Montis, A., Loi, A. G., Artico, M., Massa, S., Mai, A. and La Colla, P. 1994. Characterization of the anti-HIV-1 activity of 3, 4-dihydro-2alkoxy-6-benzyl-4-oxopyrimidines (DABOs), new nonnucleoside reverse transcriptase inhibitors. Microbiologica 17, 269-279.

5. Massa, S., Mai, A., Artico, M., Shardella, G., Tramontano, E., Loi, A. G., Scano, P. and La Colla, P. 1995. Synthesis and antiviral activity of new 3,4-dihydro-2-alkoxy-6-benzyl-4oxopyrimidines (DABOs), specific inhibitors of human immunodeficiency virus type 1 . Antiviral Chem. Chemother., 6, $1-8$.

6. Mai, A., Artico, M., Shardella, G., Massa, S., Loi, A.G., Tramontano, E., Scano, P. and Colla, P.L. 1995. Synthesis and anti-HIV-1 activity of thio analogues of dihydroalkoxy benyloxopyrimidines. J. Med. Chem. 39, 3258-3263.

7. Vig, R., Mao, C., Venkatachalam, T.K., Lisa, T.-A., Sudbeck, E.A. and Uckun, F.M. 1998. 5-Alkyl-2-[(methyl thiomethyl)thio]-6-(benzyl)-pyrimidin-4-(1H)-ones as potent non-nucleoside teverse transcriptase inhibitors of S-DABO series. Bioorg. Med. Chem. Lett. 8, 1461-1466.

8. Nizi, E., Botta, M., Corelli, F., Manetti, F., Messina, F. and Maga, G. 1998. Solid phase synthesis of 2, 6-disubstituted$4(3 \mathrm{H})$-pyrimidinones targeting HIV-1 reverse transcriptase. Tetrahedron Lett. 39, 3307-3310.

9. Miyasaka, T., Tanaka, H., Baba, M., Haykawa, H., Walkr, R. T., Balzarini, J. and De Clercq, E. 1989. A novel lead for specific anti-HIV-1 agents: 1-[(2-hydroxyethoxy)methyl]-6(phenylthio)thymine. J. Med. Chem. 32, 2507-2509.

10. Brollosy, El., Jorgensen, P.T., Dahan, B., Boel, A.M., Pedersen, E.B. and Nielsen, C. 2002. Synthesis of novel N-1 (allyloxymethyl) analogues of 6-benzyl-1-(ethoxymethyl)-5isopropyluracil (MKC-442, emivirine) with improved activity against HIV-1 and its mutants. J. Med. Chem. 45, 5721-5726

11. Bhatt, R.S., Kundu, N.G., Chwang, T.L. and Heidelberger, C. 1981. Synthesis of 5-ethynylorotic acid. J. Heterocyclic Chem. 18, 771-774.

12. Khan, M.W. and Kundu, N.G. 1999. An expeditious synthesis of 4-acyl-2,6-dioxo-1,2,3,6-tetrahydro-pyrimidines (6-acyl uracils) and 4-Acyl-6-aryl-2-oxo-2,3-dihydropyrimidines. J. Chem. Res. 20-21, 0301-0318.

13. Gershon, H. 1962. Chlorinated pyrimidines derived from orotic acid. J. Org. Chem. 27, 3507-3510. 